\title{
Metal Cation Triggered Peptide Hydrogels and Their Application in Food Freshness Monitoring and Dye Adsorption
}

\author{
Anna Fortunato (D) and Miriam Mba *(D) \\ Dipartimento di Scienze Chimiche, Università degli Studi di Padova, via Marzolo 1, 35131 Padova, Italy; \\ anna.fortunato.1@studenti.unipd.it \\ * Correspondence: miriam.mba@unipd.it
}

Citation: Fortunato, A.; Mba, M. Metal Cation Triggered Peptide Hydrogels and Their Application in Food Freshness Monitoring and Dye Adsorption. Gels 2021, 7, 85. https:// doi.org/10.3390/gels7030085

Academic Editor: Jordi Puiggalí

Received: 4 June 2021

Accepted: 5 July 2021

Published: 7 July 2021

Publisher's Note: MDPI stays neutral with regard to jurisdictional claims in published maps and institutional affiliations.

Copyright: (c) 2021 by the authors. Licensee MDPI, Basel, Switzerland. This article is an open access article distributed under the terms and conditions of the Creative Commons Attribution (CC BY) license (https:/ / creativecommons.org/licenses/by/ $4.0 /)$.

\begin{abstract}
Metal-ligand interactions have emerged as an important tool to trigger and modulate self-assembly, and to tune the properties of the final supramolecular materials. Herein, we report the metal-cation induced self-assembly of a pyrene-peptide conjugate to form hydrogels. The peptide has been rationally designed to favor the formation of $\beta$-sheet $1 \mathrm{D}$ assemblies and metal coordination through the Glu side chains. We studied in detail the self-assembly process in the presence of $\mathrm{H}^{+}$, $\mathrm{Li}^{+}, \mathrm{Na}^{+}, \mathrm{K}^{+}, \mathrm{Ca}^{2+}, \mathrm{Ni}^{2+}, \mathrm{Cu}^{2+}, \mathrm{Zn}^{2+}, \mathrm{Cd}^{2+}, \mathrm{Co}^{2+}, \mathrm{Fe}^{3+}$, and $\mathrm{Cr}^{3+}$ and found that the morphology and mechanical properties of the hydrogels are ion-dependent. Moreover, thanks to the presence of the metal, new applications could be explored. $\mathrm{Cu}^{2+}$ metallogels could be used for amine sensing and meat freshness monitoring, while $\mathrm{Zn}^{2+}$ metallogels showed good selectivity for cationic dye adsorption and separation.
\end{abstract}

Keywords: peptide; hydrogel; metallogel; self-assembly; dye adsorption; sensing; organic amines; biogenic amines; food spoilage

\section{Introduction}

Supramolecular gels are soft materials originating from self-assembly in solution of a small molecule known as low molecular weight gelator (LMWG) [1-3]. Due to the reversible nature of the non-covalent forces that are involved, supramolecular gels are stimuli-responsive materials. They may actuate gel-to-sol transition, changes in morphology, color, viscosity, fluorescence, or conductivity in response to temperature, $\mathrm{pH}$, ionic strength, ultrasounds, light, or mechanical forces [3-8]. A particular class of supramolecular gels are metallogels, in which gel formation is driven by metal-ligand interactions between metal ions and the organic LMWG [9-12]. Metals have been introduced not only to trigger self-assembly but also to tune the mechanical properties, catalytic activity [13,14], chemosensing [15], redox activity [16,17], luminescence [18,19], and self-healing properties [20-22].

Peptide based supramolecular hydrogels are of particular importance, as they find applications in tissue engineering [23,24], as biosensors [25-27], or as drug carriers [28-30]. On the other hand, peptide self-assembly has emerged also as an important tool for the design of bioinspired functional materials [31-34]. Most of the times, the formation of hydrogels is triggered by $\mathrm{pH}$ [35-37], salt concentration [38-40], or temperature changes. However, despite its potential, the investigation of peptide metallogels is still in its early stages [41]. Specific amino acids such as histidine, tyrosine, aspartic acid, or glutamic acid, possess side chains able to coordinate transition metal ions. Several studies demonstrated that metal cations can be used to trigger gel formation and tune morphology and mechanical properties in Phe-Phe dipeptide derivatives [39,42-45] and other short peptides [46-48]. Non-natural motives may be introduced into the peptide structure to favor metal binding $[42,49,50]$. Peptide-metallogels have shown new properties such as self-healing [42], catalytic activity [51], or redox activity [52]. 
The detection of volatile amines is of great interest as they are widely employed in the chemical, pharmaceutical, agricultural and food industries [53-56]. Biogenic amines (BA) (i.e., histamine, tyramine, putrescine, cadaverine, spermine, spermidine, tryptamine and serotonine) are produced and accumulated in food products as a result of fermentation or decomposition, and so they serve as freshness markers [57-62]. Foods can take many transit routes and experience different storage conditions before consumption, and thus "best before" or "use by" dates do not always ensure product freshness. For these reasons, in recent years, much effort has been exerted in order to develop smart packaging based on visual colorimetric sensors for food freshness monitoring in a consumer-friendly manner [63-65]. To facilitate the use in food packaging, a system able to detect BA vapors is desirable. In this context, supramolecular gels have been largely used for the fluorescent and colorimetric detection of organic volatile amines and biogenic amines [66-69], including some examples of amino acid based supramolecular gels reported by Xue and coworkers [70-72]. On the other hand, examples employing supramolecular metallogels are rare. Sengupta reported a $\mathrm{Cu}^{2+}$ metallogel that shows colorimetric changes in the presence of ammonia, diethylamine, trimethylamine, and pyridine vapors [73]. More recently, a $\mathrm{Ni}^{2+}$ metallogel was reported by Tang and coworkers [74] for the colorimetric detection of biogenic amines that could be used to monitor meat spoilage, while $\mathrm{Gu}$ and coworkers reported $\mathrm{a} \mathrm{Tb}^{3+}$ gel able to detect organic amines at the sub-ppm level [75].

Organic dyes are an important class of organic compounds widely used in different industries, in particular in the textile industry. As such, they have become a critical source of water pollution and, since these pollutants are toxic and cause health disorders and perturbation of aquatic life, their removal from industrial waste water has come to be extremely important [76,77]. Different strategies have been developed for dye removal [77], among them, adsorption of dyes is an efficient low-cost and operationally simple approach [78]. Hydrogels and xerogels possess two intrinsic features that make them good candidates to be used as adsorbent materials for water remediation: a porous network and functional groups that can interact with guest molecules [79]. Consequently, peptide supramolecular gels have been extensively used as dye adsorption materials [80-85]. The use of peptide metallogels as dye adsorbents is almost unexplored, but in principle their superior mechanical properties should play a positive role. Qin and coworkers reported a $\mathrm{Mg}^{2+} / \mathrm{L}-$ glutamic acid dendron shrinkable gel capable of ionic dye adsorption and separation [86]. Ray and coworkers developed a $\mathrm{Cu}^{2+} /$ peptide bolaamphiphile hydrogel that efficiently adsorbed various ionic and nonionic dyes [87].

This work aims to further explore the potential of peptide metallogels. While most studies have focused on tuning morphology and mechanical properties, we are looking for new properties and applications derived from the presence of the metal. Herein, the metal-triggered formation of fluorescent hydrogels from pyrene-peptide conjugate 1 has been explored (Figure 1). The effect of different metal cations on gelation ability, morphology, mechanical and optical properties has been studied. We demonstrate that the $\mathrm{Cu}^{2+}$ triggered hydrogels are capable of amine sensing and can be used as food freshness indicators, while $\mathrm{Zn}^{2+}$ hydrogels were found to be able to selectively adsorb cationic dyes from their aqueous solutions.

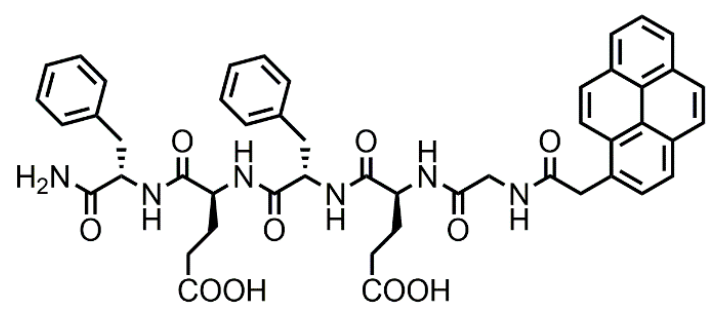

Figure 1. Structure of the pyrene-peptide conjugate $\mathbf{1 .}$ 


\section{Results and Discussion}

\subsection{Design and Synthesis of $\mathbf{1}$}

The peptide amphiphile $\mathbf{1}$ was designed to incorporate a fluorescent pyrene chromophore at the $\mathrm{N}$-terminal position of a $\beta$-sheet forming pentapeptide containing two Glu residues in the sequence able to coordinate metal ions. Glu residues alternate with hydrophobic Phe residues, as this alternation is known to favor the formation of $1 \mathrm{D} \beta$-sheet assemblies [88-90]. The synthesis was performed using standard Fmoc-based peptide synthesis protocols on a Rink amide resin. The identification of the product was assessed by NMR, FT-IR, and MS (Figures S1-S3, see supporting information for details).

\section{2. $p H$-Triggered Gelation}

1 dissolved in water at alkaline $\mathrm{pH}(\mathrm{pH} \approx 10)$ as a result of electrostatic repulsion between the deprotonated Glu side chains. At $0.005 \%$ concentration, the fluorescence spectrum of the solution was dominated by the characteristic emission of pyrene monomeric species [91]. However, at $0.5 \%$ concentration a new structureless band appears at $485 \mathrm{~nm}$ (Figure S4). The broader UV-Vis profile and nonsilent CD spectra of the $0.5 \%$ solution point to the formation of small aggregates at high concentrations (Figures S5 and S6). Acidification with a solution of $\mathrm{HCl}$ led to hydrogel formation within seconds. The minimum gelator concentration was $0.5 \%$. The hydrogel was self-supporting and thermoreversible, with a Tgel of $107^{\circ} \mathrm{C}$. Thus, Tgel is higher than the boiling point of the solvent. This behaviour has been observed before in literature and can be ascribed to a remarkable stability of the 3D network [92-95]. The UV-Vis absorption spectrum of the gel showed the typical pyrene absorption band above $300 \mathrm{~nm}$, but it was red-shifted, broader, and less structured when compared with the non-gelled sample (Figure 2a). These signatures suggest strong $\pi-\pi$ interactions within the chromophores upon self-assembly. The emission spectrum of the gel was partially quenched and the vibrational peaks from to the monomeric species were still detected below $425 \mathrm{~nm}$ (Figure $2 \mathrm{~b}$ ). However, a new red-shifted broad centered at $475 \mathrm{~nm}$ appeared. This data further confirms the presence of aromatic $\pi-\pi$ interactions. To get more insight, ATR-FTIR studies were performed on the xerogels. We examined the region between 1800 and $1430 \mathrm{~cm}^{-1}$ (Figure 2d). The peptide backbone gives rise to two bands in this region: the amide I band $\left(\sim 1650 \mathrm{~cm}^{-1}\right)$, arising mainly from the $\mathrm{C}=\mathrm{O}$ stretching, and the amide II band $\left(\sim 1550 \mathrm{~cm}^{-1}\right)$, due to a combination of $\mathrm{N}-\mathrm{H}$ in-plane bending and $\mathrm{C}-\mathrm{N}$ stretching. It is well known that the secondary structure of peptides and proteins can be inferred from the position of the amide I [96]. Analysis of the ATR-IR spectrum showed a predominant Amide II band at $1630 \mathrm{~cm}^{-1}$, shifted to lower frequencies when compared to the non-aggregated sample (Figure S7). This signal is within the range expected for the $\beta$-sheet structure [97], and similar values have been reported for other short self-assembling peptides [37]. Moreover, in this region the $\mathrm{C}=\mathrm{O}$ stretching of the Glu side chain is also observed. The protonated $\mathrm{COOH}$ gives rise to a single stretching at $1715 \mathrm{~cm}^{-1}$. The formation of extended $\beta$-sheet structures was confirmed by the presence of a strong negative signal at $215 \mathrm{~nm}$ in the circular dichroism spectrum (Figure 2c) [98-100]. Interestingly, Cotton effects were also evident between 300 and $400 \mathrm{~nm}$, in the absorption region of the pyrene chromophore, suggesting a chiral arrangement of this chromophore within the supramolecular assembly [101]. 

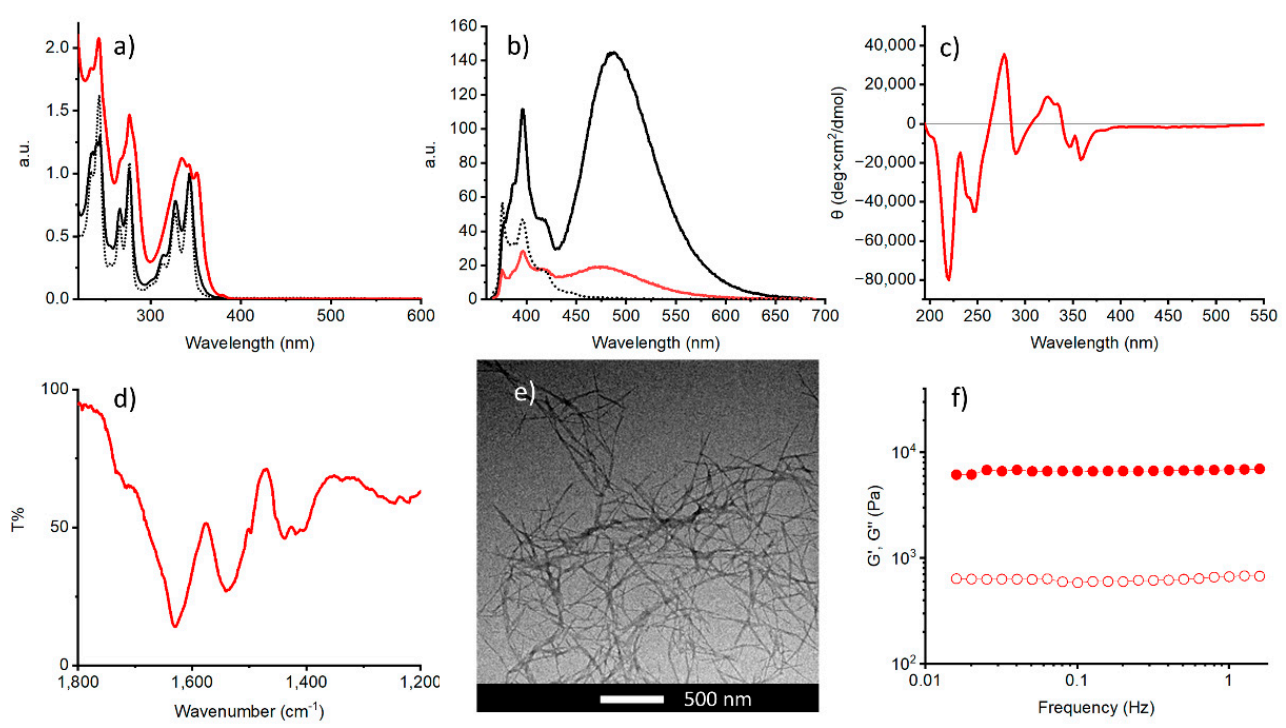

Figure 2. (a) UV-Vis absorption and (b) emission spectra of the $\mathrm{pH}$-triggered gel (red line) and the aqueous solutions of $\mathbf{1}$ at $0.5 \%$ (solid black line) and $0.005 \%$ concentration (black dotted line); (c) ATRFTIR, (d) CD spectrum, (e) TEM images and (f) frequency sweep experiment of the $\mathrm{HCl}$ triggered gel at $0.5 \%$ concentration, $G^{\prime}$ is indicated with filled circles and $G^{\prime \prime}$ with open circles. ATR-IR and TEM were recorded using dried samples.

The morphology of the gel was studied by transmission electron microscopy (TEM), which showed the formation of fibrous networks. Fibers were up to $800 \mathrm{~nm}$ long with a diameter of $21 \pm 5 \mathrm{~nm}$ (Figure 2e).

The mechanical properties of the gel were studied by oscillatory rheology. As expected for viscoelastic materials, the storage modulus $\left(\mathrm{G}^{\prime}\right)$ dominated over the viscous counterpart $\left(G^{\prime \prime}\right)$ within the linear viscoelastic region (LVE) (Figure 2f), as expected for a gel material. In the tested LVE range, the storage and loss moduli were minimally sensitive to the frequency and did not cross each other. In strain sweep experiments the cross-over point $\left(G^{\prime}=G^{\prime \prime}\right)$ was reached at $8 \%$ strain (Figure $\mathrm{S} 8$ ).

\subsection{Metal Ion Triggered Gelation}

A series of metal ions $\mathrm{Li}^{+}, \mathrm{Na}^{+}, \mathrm{K}^{+}, \mathrm{Ca}^{2+}, \mathrm{Ni}^{2+}, \mathrm{Cu}^{2+}, \mathrm{Zn}^{2+}, \mathrm{Cd}^{2+}, \mathrm{Co}^{2+}, \mathrm{Fe}^{3+}$, and $\mathrm{Cr}^{3+}$ were explored. Hydrogelation was studied by addition of different chloride salts to a $0.5 \%$ solution of 1 at basic $\mathrm{pH}$. Different concentrations of salt were tested. Gelation triggered by monovalent cations required up to 12 equivalents of salt and took 5-10 $\mathrm{min}$. On the other side, instant gel formation was observed upon addition of stoichiometric amounts of divalent and trivalent cations (Figure S9). Next, we varied the initial concentration of 1 and found that the minimum gelator concentration was reduced from $0.5 \%$ to $0.25 \%$ in the case of divalent and trivalent cations. We hypothesize that in the case of divalent and trivalent cations, metal complexation allows us to obtain a stable 3D network at lower concentrations. Similar trends have been reported before in the literature for other metal-triggered hydrogels [46].

To investigate the role of the different non-covalent forces involved in the formation of supramolecular hydro-metallogels, different spectroscopic techniques were employed. In the present case, UV-Vis and emission spectroscopies were used to assess the participation of $\pi-\pi$ stacking interactions between pyrene chromophores. Meanwhile, ATR and CD spectroscopies were used to assess intermolecular hydrogen bond formation.

The profile of the UV-Vis absorption spectra of metal-triggered gels (Figure 3a,c) was in all cases broadened and red-shifted when compared to the non-aggregated state, as expected for the formation of supramolecular structures through strong $\pi-\pi$ stacking inter- 
actions. This effect was more prominent in the case of salts bearing divalent and trivalent cations in which, in addition, a high scattering contribution was evident. The emission of metal-triggered hydrogels was strongly quenched (Figure $3 b, d$ ), in particular for $\mathrm{Cr}^{3+}$, $\mathrm{Fe}^{3+}, \mathrm{Cu}^{2+}, \mathrm{Co}^{2+}$, and $\mathrm{Ni}^{2+}$. The profile of the monomeric pyrene species was negligible in the emission spectra, which was indeed dominated by a broad red-shifted band.
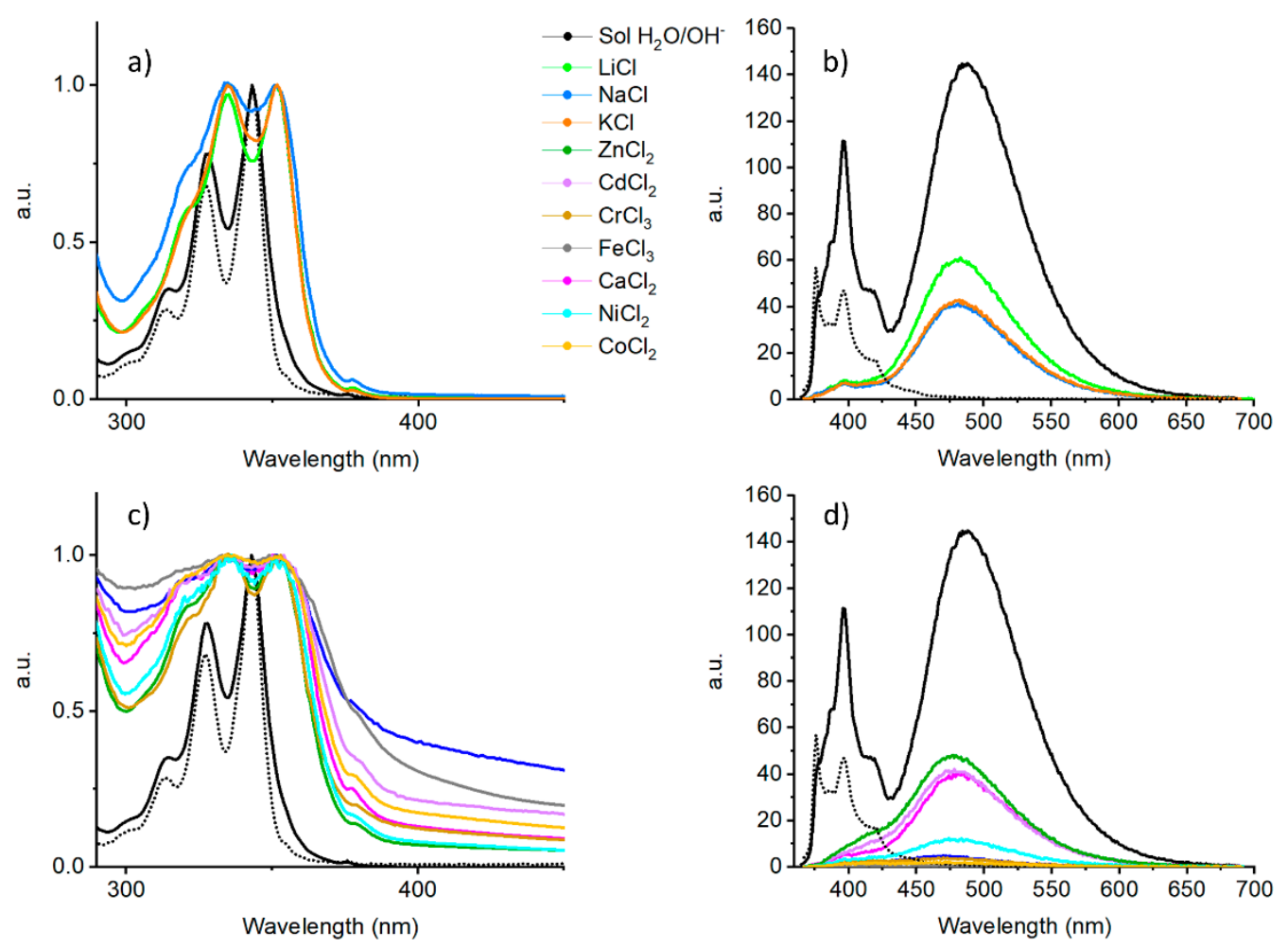

Figure 3. (a) Normalized UV-Vis absorption and (b) non-normalized emission spectra $\left(\lambda_{\mathrm{exc}}=352 \mathrm{~nm}\right)$ of the monovalent cation triggered gels; (c) Normalized UV-Vis absorption and (d) non-normalized emission spectra $\left(\lambda_{\text {exc }}=352 \mathrm{~nm}\right)$ of the divalent and trivalent cation triggered gels. The data of the aqueous solutions of $\mathbf{1}$ at $0.5 \%$ (solid black line) and $0.005 \%$ concentration (black dotted line) have been included for comparison.

In the ATR spectra of the xerogels (Figures S10 and S11), we observed the amide I band at $1632-1623 \mathrm{~cm}^{-1}$ shifted to lower wavenumber values when compared with the non-aggregated state. This shift indicates the formation of extended hydrogen bonding, in particular the position of the bands indicates the formation of $\beta$-sheet structures. The $C=C$ stretching of the Phe side chain gives rise to the weak band at $1598 \mathrm{~cm}^{-1}$. In this region we also expected to see bands arising from the carboxylate anion: an asymmetric stretching $\left(v_{\mathrm{as}}\left(\mathrm{COO}^{-}\right)\right)$at $\sim 1560 \mathrm{~cm}^{-1}$ and a symmetric one $\left(v_{\mathrm{as}}\left(\mathrm{COO}^{-}\right)\right)$at $\sim 1404 \mathrm{~cm}^{-1}$. The broad band observed around $1540 \mathrm{~cm}^{-1}$ arises from the overlap of the amide II and the $v_{\text {as }}\left(\mathrm{COO}^{-}\right)$. Next, three bands are found at circa 1453, 1440, and $1404 \mathrm{~cm}^{-1}$. The first two are caused by the $\mathrm{CH}$ bending of the side chains, the last one is the $v_{\text {as }}\left(\mathrm{COO}^{-}\right)$. As expected, no stretching of the protonated $\mathrm{COOH}$ was detected. Thus in metallogels the Glu side chain is in the ionized form.

CD spectra were recorded for gels triggered by group I monovalent cations. The measurement was not possible when salts of divalent or trivalent cations were used to trigger gel formation, due to the high contribution of scattering. The CD spectra (Figure S12) were dominated by a negative peak at $214 \mathrm{~nm}$, which suggests extensive $\beta$-sheet formation [98-100]. The profile of the $\mathrm{Na}^{+}$triggered gel was much less intense in this region, probably due to the presence of bigger assemblies that affected the measurement. CD signals were also detected within the range of 300-400 $\mathrm{nm}$, where only the pyrene contribution is expected. Thus, at 
least when monovalent cations are used, pyrene moieties take part in a chiral supramolecular assembly.

The morphology of the metallogels was studied by TEM (Figure 4 and Figures S13-S24). Monovalent cations gave rise to entangled fibrillar networks. Fibers were various microns long and, in the case of $\mathrm{Na}^{+}$and $\mathrm{K}^{+}$, a helical twist of the fibers was observed. When divalent and trivalent cations are used, TEM images show in general the formation of shorter assemblies. Thus, it seems that when metal cations are used the growth of 1D structures is less effective. Three of the samples deserve special mention: the gels triggered by $\mathrm{Cd}^{2+}$, $\mathrm{Cu}^{2+}$, and $\mathrm{Fe}^{3+}$. As seen in Figure 4, superhelices were found in $\mathrm{Cd}^{2+}$ triggered gels. $\mathrm{Fe}^{3+}$ gave rise to the assemblies with the lowest aspect ratios. The supramolecular structures had a rod-like shape. On average, they measured $40 \pm 8 \mathrm{~nm}$ in length with a diameter of $8 \pm 2 \mathrm{~nm}$. The inability of $\mathrm{Fe}^{3+}$ cation to form nanofibers has been ascribed before to strong peptide-metal interactions that inhibit nanofiber formation [43]. On the other hand, when $\mathrm{Cu}^{2+}$ was used, the TEM micrographs showed the coexistence of spherical structures, fibers, and worm-like micelles. We hypothesized that the difference in morphology may arise from different factors. First, while monovalent cations are expected to promote self-assembly by a simple screening of the charges, divalent and trivalent cations are on the other hand are able to form complexes. Metal complexation gives rise to more rigid structures and enhances cross-linking, but truncates the 1D growth through $\beta$-sheet hydrogen bonding, which explains the formation of shorter supramolecular structures. Second, the different coordination modes of the metal cations and the strength of the metal-ligand interaction will also affect the final morphology of the aggregates.
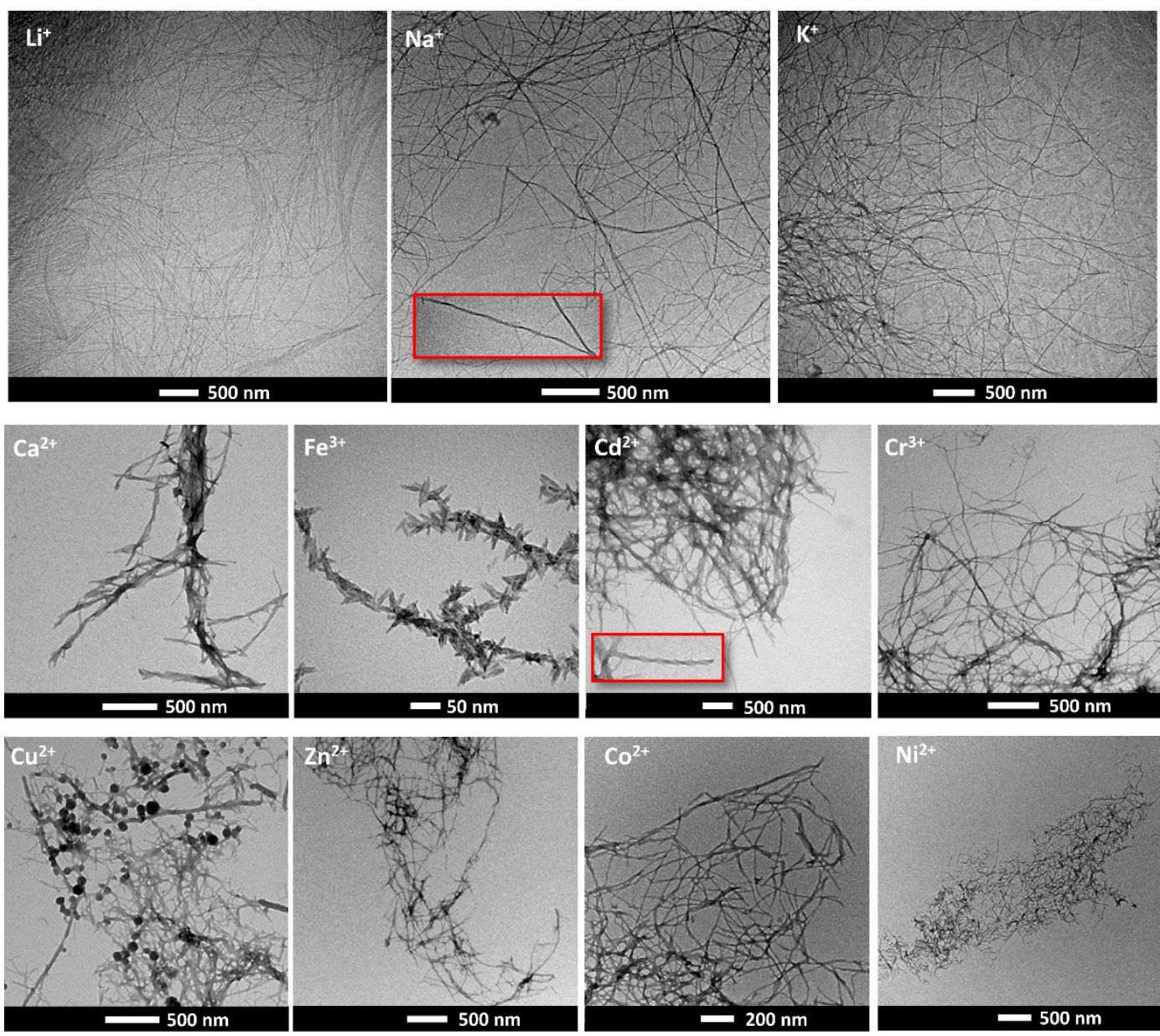

Figure 4. Transmission electron microscopy (TEM) images of the cation induced metallogels. Images were recorded in dry samples without the use of stain. 
The mechanical properties of the metallogels were examined by means of rheology. Frequency sweep measurements (Figure 5) showed that in all cases the storage modulus $\left(G^{\prime}\right)$ was higher than the loss modulus $\left(G^{\prime \prime}\right)$ by at least one order of magnitude in the linear viscoelastic region (Table S1 of the SI). This behaviour confirms the gel nature of the materials. The $\mathrm{G}^{\prime}$ values in gels induced by monovalent cations were lower than the $\mathrm{G}^{\prime}$ of the pH-triggered gel, indicating less stiff gels. Strain sweep experiments, on the other hand, indicated that the gels break down at higher strain values (Figure S25).
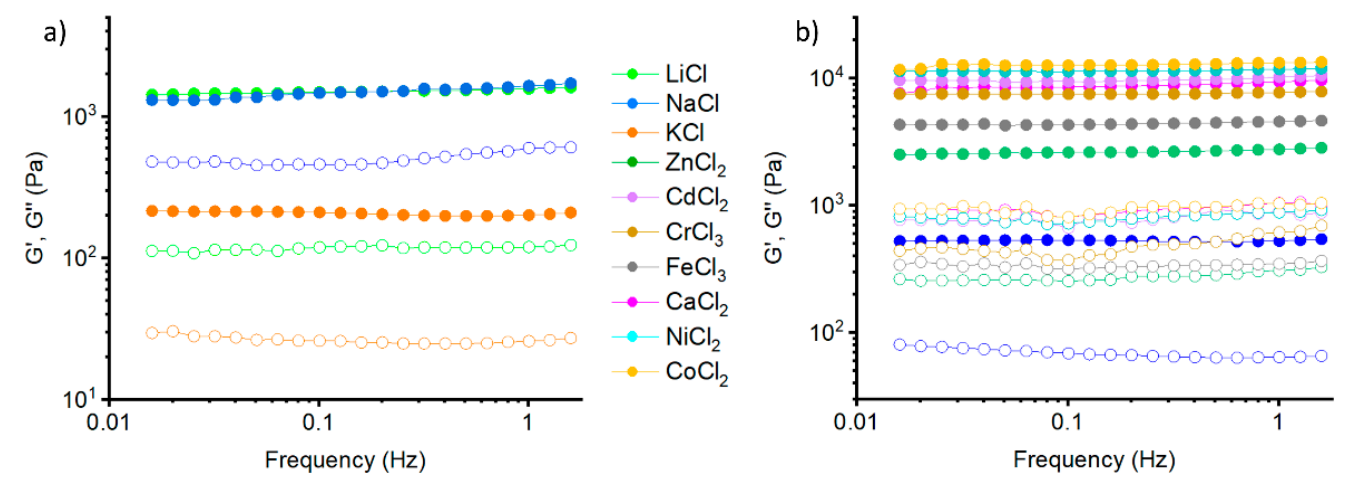

Figure 5. Frequency sweep experiments of metallogels triggered by (a) monovalent cations and (b) divalent and trivalent metal cations. $G^{\prime}$ values are indicated with filled circles while $G^{\prime \prime}$ values are indicated with open circles.

Except for $\mathrm{Cu}^{2+}$, divalent and trivalent cations gave stiffer gels than monovalent cations and lower strain values were necessary to achieve the gel-to-sol transition (Table S1 of the SI). We hypothesized that metal complexation increases stiffness, however stiffer structures adapt less to strain changes and so gel failure is achieved at lower strain values. When compared to the $\mathrm{HCl}$-gel, divalent and trivalent cations required lower strain deformations for gel failure (except for $\mathrm{Cu}^{2+}$ ) (Figure S26). On the other side, only $\mathrm{Co}^{2+}$ and $\mathrm{Ni}^{2+}$, which according to the Irwin-Williams series are predicted to possess higher complex stability, had significant a higher $\mathrm{G}^{\prime}$ than the $\mathrm{pH}$-triggered gel. The $\mathrm{Cu}^{2+}$ triggered gel is a case apart. It showed the lowest $\mathrm{G}^{\prime}$ value of the series. This behaviour is a consequence of the particular morphology of the hydrogel. A weaker 3D network is expected, as spherical assemblies do not favour an effective cross-linking.

\subsection{Detection of Amines and Meat Freshness Monitoring}

We investigated the ability of the $1-\mathrm{Cu}^{2+}$ metallogel to detect volatile amine vapors. We expected to observe colorimetric changes upon exposure to amines due to a change in the coordination environment of the copper ions, which are known to coordinate amines to give blue complexes. For sensing experiments, films were obtained on a glass slide by drop-casting a solution of $\mathbf{1}$ and careful addition of $\mathrm{CuCl}_{2}$ solution. The obtained hydrogel was light blue. The hydrogel was then exposed to amine vapors in a closed chamber. In particular, the response to ammonia, methylamine, diethylamine and triethylamine was investigated. The hydrogel changes from light blue to dark blue color in the presence of ammonia and methylamine, while it changes to violet color when exposed to diethylamine and trimethylamine (Figure S27). The gel recovered its initial color after exposure to air for several hours or upon brief exposure to $\mathrm{HCl}$ vapors. In the presence of air, the aminecoordinated gel reverted to the original state, inducing a rearrangement of the copper ion coordination. Encouraged by these results, we decided to investigate the potential of the $1-\mathrm{Cu}^{2+}$ gel in monitoring chicken breast spoilage. To do so, a controlled spoilage environment was used as a model of packaging. A piece of chicken breast and a piece of metallogel were introduced to a Petri dish while avoiding contact with each other, and then the dish was sealed. Two experiments, at $25^{\circ} \mathrm{C}$ and $4{ }^{\circ} \mathrm{C}$, were performed (Figure 6). When the sample was kept at $4{ }^{\circ} \mathrm{C}$, no color changes were detected even after three days. 
On the other hand, when the sample was stored at $25{ }^{\circ} \mathrm{C}$ the metallogel changed its color from light blue to dark brown in only $12 \mathrm{~h}$, indicating meat degradation. This is, as far as we know, the first example of a peptide-metallogel sensor for monitoring food spoilage.
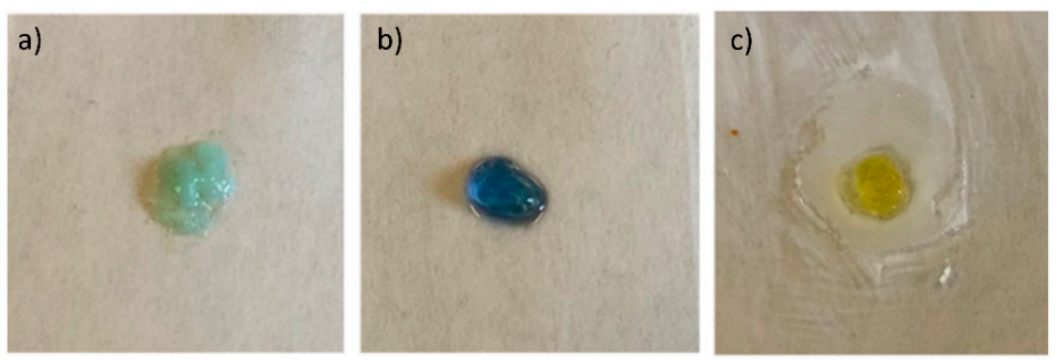

d)

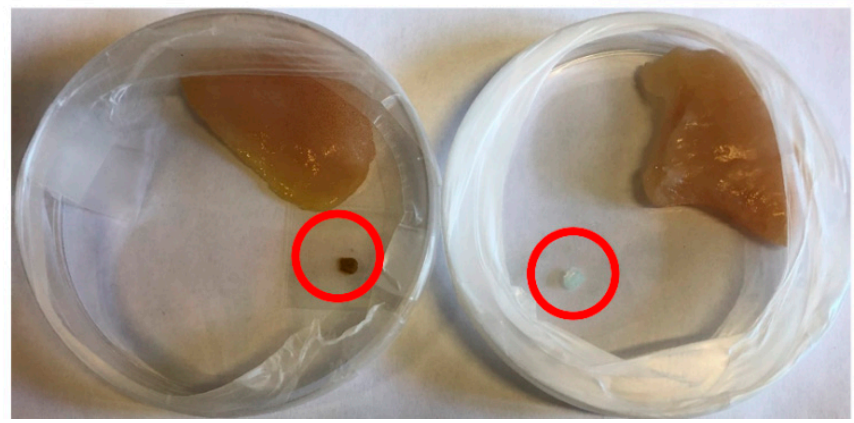

Figure 6. Images of the 1-Cu ${ }^{2+}$ gel (a) as prepared, (b) after exposure to ammonia vapors, and (c) after exposure to $\mathrm{HCl}$ vapors, $(\mathrm{d})$ colorimetric responses of the $1-\mathrm{Cu}^{2+}$ gel when exposed to chicken meat stored at $25^{\circ} \mathrm{C}$ (left) and $4{ }^{\circ} \mathrm{C}$ (right).

\subsection{Selective Cationic Dye Adsorption}

As pointed out in the Introduction, dye adsorption is a simple and efficient way to remove dyes from wastewater. We investigated the dye removal ability of our hydrogels using two common dyes: methylene blue and methyl orange. First, a qualitative test was performed in both $\mathrm{pH}$ and cation triggered hydrogels. To do so, $0.75 \mathrm{~mL}$ of a $15 \mathrm{mg} / \mathrm{L}$ solution of methylene blue was carefully added to a vial containing $0.25 \mathrm{~mL}$ of the corresponding hydrogels obtained at $0.5 \%$ concentration. The samples were allowed to stand undisturbed at room temperature. We observed that gels triggered by $\mathrm{H}^{+}, \mathrm{Ca}^{2+}, \mathrm{Fe}^{3+}$, and monovalent cations fall apart upon dye absorption. On the other hand, gels triggered by divalent transition metal cations remain intact (Figure S28). Among them, the $\mathrm{Zn}^{2+}$ triggered hydrogel showed the fastest dye adsorption (Figures S29-S31) and so we continued the dye removal studies with it. To facilitate adsorbent separation and recovery, and to avoid diffusion effects, we lyophilized the $1-\mathrm{Zn}^{2+}$ metallogel and performed our studies on the xerogel. Adsorption studies were performed using the cationic dye methylene blue, the anionic dye methyl orange, and a mixture of both (Figure 7 and Figures S32-S34). In a typical experiment, $4 \mathrm{mg}$ of xerogel were introduced to a vial together with $2.7 \mathrm{~mL}$ of a $10 \mathrm{mg} / \mathrm{mL}$ aqueous solution of the dye. After $30 \mathrm{~min}$, it was evident that the xerogel was able to completely adsorb methylene blue, as the water appeared colorless while the xerogel was dark blue. On the other side, methyl orange was not adsorbed by the xerogel and when a mixture of both dyes was used, the xerogel became blue while the aqueous phase remained orange, indicating the selective adsorption of the cationic dye. The process was also monitored by UV-Vis spectroscopy. The $668 \mathrm{~nm}$ and $463 \mathrm{~nm}$ wavelengths were used to monitor methylene blue and methyl orange, respectively. As show in Figure 7, the removal efficiency for methylene blue was remarkable. The concentration of the dye in the solution decreased quickly and $89 \%$ of the dye was removed after only 20 min, while methyl orange was not removed from water. In a mixture, the intensity of the absorption of methylene blue decreases with time, while the absorption of methyl orange remains unaffected. The results indicate that the $1-\mathrm{Zn}^{2+}$ xerogel selectively removes cationic dyes 
from water. Selectivity is related to the attractive electrostatic interaction between the deprotonated Glu side chains of the peptide and the positive charge of the thiazine dye.
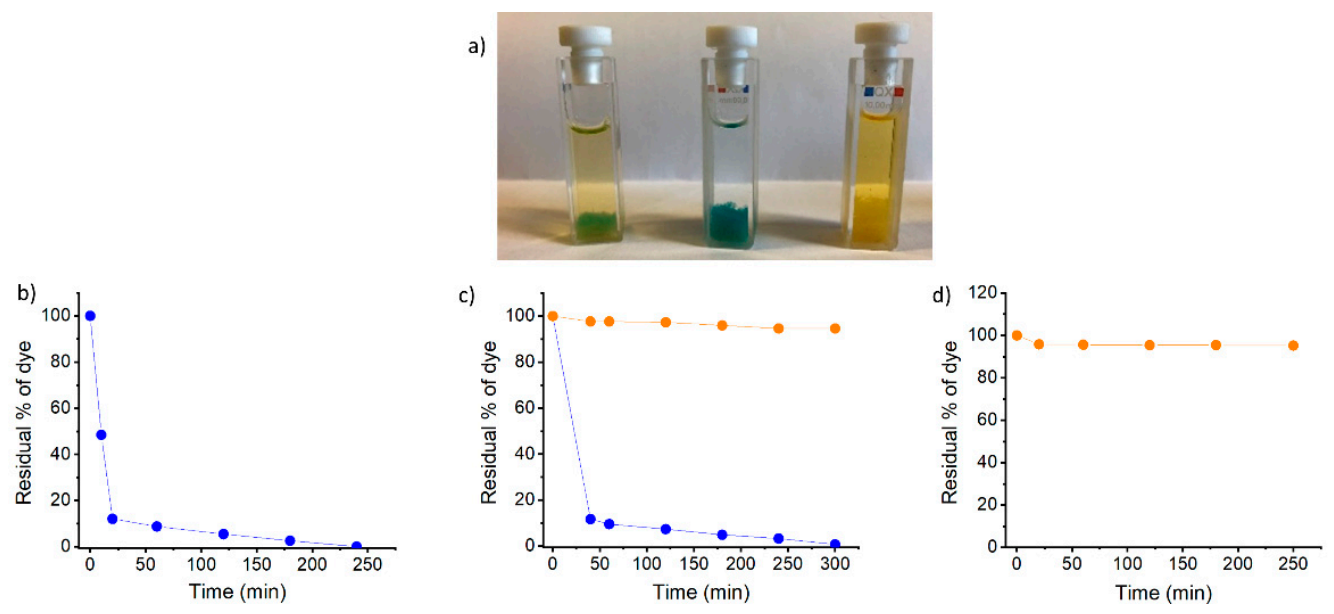

Figure 7. (a) Image of cuvettes containing $1-\mathrm{Zn}^{2+}$ xerogels upon dye adsorption, from left to right methylene blue mixed with methyl orange, methylene blue, and methyl orange. Dye absorption abilities of the 1- $\mathrm{Zn}^{2+}$ xerogel: (b) Evolution over time of the residual concentration (\%) of methylene blue $(668 \mathrm{~nm}),(\mathrm{c})$ Evolution over time of the residual concentration (\%) of dye in a 1:1 mixture of methylene blue (668 nm, blue dots) and methyl orange (463 nm, orange dots) (d) Evolution over time of the residual concentration (\%) of methyl orange (463 nm).

\section{Conclusions}

In summary, we have described the cation-induced self-assembly of a pyrene-peptide conjugate. The self-assembly process was studied at acidic $\mathrm{pH}$ and at alkaline $\mathrm{pH}$ by the addition of monovalent, divalent, and trivalent cations. In particular, the interaction of the anionic Glu side chain with the metal cation was exploited to induce self-assembly. Our studies also demonstrated that $\beta$-sheet hydrogen bonding and $\pi-\pi$ interactions between pyrene moieties contribute to the formation of the supramolecular assemblies. We found that the morphology and mechanical properties of the resulting hydrogels are cationdependent. Long, flexible fibrillar structures were obtained when gelation was triggered by $\mathrm{pH}$ or addition of monovalent cations. Shorter, more rigid structures were obtained when divalent and trivalent cations were used. The $\mathrm{Cu}^{2+}$ metallogel had a particular morphology, and the coexistence of fibers, warm-like micelles and spherical structures was found. This metallogel was used for the colorimetric detection of organic volatile amines, and we demonstrated its utility in monitoring meat spoilage. Moreover, thanks to the particular porosity and mechanical properties, the $\mathrm{Zn}^{2+}$ metallogel showed a good ability for selective dye adsorption.

\section{Materials and Methods}

\subsection{General Methods}

ESI-MS experiments were performed on an ESI-TOF MarinerTM BiospectrometryTM Workstation of Applied Biosystems by flow injection analysis using methanol/1\% formic acid as a mobile phase. ${ }^{1} \mathrm{H},{ }^{13} \mathrm{C}$, and $2 \mathrm{D}$ NMR were recorded at $289 \mathrm{~K}$ on a Bruker Avance III 300 spectrometer using the partially deuterated solvent as internal reference. Chemical shifts $(\delta)$ are expressed in parts per million (ppm). The multiplicity of a signal is indicated as: $\mathrm{s}$ (singlet), $\mathrm{d}$ (doublet), $\mathrm{t}$ (triplet), $\mathrm{dd}$ (doublet of doublets), $\mathrm{dt}$ (doublet of triplets), $\mathrm{td}$ (triplet of doublets), q (quartet), and $\mathrm{m}$ (multiplet). The acronym "br" indicates a broadened signal. FT-IR absorption spectra were recorded on an FT-IR Perkin-Elmer, model 1720X spectrophotometer, in $\mathrm{KBr}$ disk, at a nominal resolution of $2 \mathrm{~cm}^{-1}$, averaging 100 scans. In the case of hydrogels, IR spectra were recorded using the xerogels. UV-Vis absorption spectra were recorded on a Varian Cary 50 spectrophotometer at $25^{\circ} \mathrm{C}$. All spectra are 
baseline corrected. A rectangular cell with detachable windows and optical path of $0.02 \mathrm{~cm}$ was used for the analysis of gelled samples. For non-gelled samples, a reduce volume quartz cell with $1 \mathrm{~cm}$ or $0.1 \mathrm{~cm}$ optical path was used. General methodology for gel samples: gels were prepared in a glass vial; a small amount was transferred to the sample chamber and the cell was closed with the top window taking care not to form bubbles. Emission spectra were recorded on a Varian CaryEclipse spectrophotometer at $25^{\circ} \mathrm{C}$. A quartz cell with an optical path of $10 \times 4 \mathrm{~mm}$ and volume $1400 \mu \mathrm{L}$ was used for gel samples. A quartz cell with optical path of $10 \times 10 \mathrm{~mm}$ and volume $3 \mathrm{~mL}$ was used for the solutions. General methodology for gel samples: Gels were prepared in a glass vial and transferred to the cuvette without amendment such as dilution. CD spectra were recorded on a Jasco $\mathrm{J}-1500$ instrument at $25^{\circ} \mathrm{C}$ and were baseline corrected. Every $\mathrm{CD}$ spectrum was obtained as an average of 32 or 64 measurements. The spectra are expressed in terms of total molar ellipticity $\left(\mathrm{deg} \cdot \mathrm{cm}^{2} \cdot \mathrm{dmol}^{-1}\right)$. A rectangular cell with detachable windows and optical path of $0.02 \mathrm{~cm}$ was used for the analysis of gelled samples. For non-gelled samples, a reduce volume quartz cell with $1 \mathrm{~cm}$ or $0.1 \mathrm{~cm}$ optical path was used. General methodology for gel samples: gels were prepared in a glass vial; a small amount was transferred to the sample chamber and the cell was closed with the top window taking care not to form bubbles. Transmission electron microscopy (TEM) images were recorded on a Jeol 300PX instrument. A glow discharged carbon coated grid was floated on a small drop of solution and the excess was removed by using \#50 hardened Whatman filter paper. Samples of the gels were prepared in two different ways: (a) by dropping a small amount of gel into a glow discharged carbon coated grid and removing the excess gel with \#50 hardened Whatman filter paper; (b) gels were diluted prior to analysis, a small amount of each sample has been deposited directly on a glow discharged carbon coated grid and no staining has been used. The excess has been removed by \#50 hardened Whatman filter paper. The images were analysed with the ImageJ program. Rheological analyses were carried out on a Kinexus $\mathrm{Lab}+$ rheometer with a parallel plate geometry. Hydrogel samples were prepared on a total volume of $2 \mathrm{~mL}$ and immediately transferred onto the plate. An anti-evaporation chamber was used to prevent drying of the samples and temperature was set at $25^{\circ} \mathrm{C}$. Frequency sweep tests were carried out between $0.6-0.0016 \mathrm{~Hz}$ at a constant strain. Strain measurements were carried out between $0.01-110 \%$ at a constant frequency of $1 \mathrm{~Hz}$.

\subsection{Synthesis of 1}

Compound 1 was synthesized using standard solid phase 9-fluorenylmethoxycarbonyl (Fmoc) chemistry on Rink Amide resin. When not in use, the resin was dried and stored in a freezer with the amino-terminus Fmoc-protected. The MBHA Rink Amide resin was purchased from Irish Biotech (Marktredwitz, Germany) (commercial loading $0.68 \mathrm{mmol} / \mathrm{g}$ ); $O$-Benzotriazole- $N, N, N^{\prime}, N^{\prime}$-tetramethyluronium hexafluorophosphate (HBTU), 1-Hydroxybennzotriazole hydrate (HOBt), N,N-Diisopropylethylamine (DIPEA), Piperidine, trifluoroacetic acid (TFA), triisopropylsilane (TIPS), Fmoc- amino acids and solvents were purchased from Sigma-Aldrich-Merck (Darmstadt, Germany). SPPS was performed in a standard vessel for manual SPPS equipped with a glass frit and two outlets. The stirring was achieved by bubbling nitrogen from below, thus all the steps have been carried out under $\mathrm{N}_{2}$ flux. A washing step implies $1 \mathrm{~min}$ of stirring and then removal of solvent. In general, $10 \mathrm{~mL}$ of solvent must be used for $1 \mathrm{~g}$ of resin. The resin was prepared by dumping $1 \mathrm{~g}$ of resin into the SPPS vessel and then $10 \mathrm{~mL}$ of dimethylformamide (DMF) were added for resin swelling and stirred gently for $30 \mathrm{~min}$. Fmoc deprotection was performed by mixing the resin in a piperidine/DMF (2:8) solution for $15 \mathrm{~min}(\times 2$, then washing with DMF $(\times)$. For amino acid couplings we used the following protocol: 4.0 eq. (relative to the resin loading) of Fmoc-protected amino acid were activated externally with 3.9 eq. of HBTU, 3.9 eq. of HOBt and 12 eq. of DIPEA in DMF. This mixture was then added to a peptide chamber containing the Rink Amide resin and mixed for $3 \mathrm{~h}$. All coupling and deprotection steps were monitored using a Kaiser test on a few resin beads that were removed from the peptide chamber after drying with dichloromethane (DCM). If necessary, 
the coupling step was repeated. The coupling with the pyrene functionalized core was performed using 2 eq. of 1-Pyreneacetic acid, 1.9 eq. of HBTU and HOBt and 6 eq. of DIPEA. The reaction was performed for $2 \mathrm{~h}$. The solvent was removed and the resin was washed with DMF $(3 \times 10 \mathrm{~mL})$, DCM $(3 \times 10 \mathrm{~mL})$, and DMF $(2 \times 10 \mathrm{~mL})$. Cleavage from the resin and removal of side-chain protecting groups was accomplished by stirring the resin with $10 \mathrm{~mL}$ of TFA, water, and TIPS (95:2.5:2.5) for $3 \mathrm{~h}$. The solvents were collected in a flask and the resin (that eventually turned red) was washed with DCM $(3 \times 10 \mathrm{~mL})$. Solvents collected were concentrated in rotavapor (a potassium hydroxide trap was used) to the half. DCM was added and the volatiles were evaporated again. The process was repeated three times, after which the solvents were evaporated to dryness. The product was precipitated from cold diethyl ether and the precipitated peptide was isolated by centrifugation and lyophilized. A white powder was obtained (89\% yield).

ESI-MS: $[\mathrm{M}+\mathrm{H}]^{+}$, calculated for $\mathrm{C}_{48} \mathrm{H}_{49} \mathrm{~N}_{6} \mathrm{O}_{10}$ 869.34, found: 869.3. [M+Na] ${ }^{+}$calculated for $\mathrm{C}_{48} \mathrm{H}_{48} \mathrm{~N}_{6} \mathrm{NaO}_{10}$ 891.34, found 891.4.

${ }^{1} \mathrm{H}-\mathrm{NMR}$ (DMSO-d6, $\left.300 \mathrm{MHz}\right): \delta 12.02(\mathrm{bs}, \mathrm{COOH}), 8.44-8.30(\mathrm{~m}, 2 \mathrm{H}), 8.28-7.89(\mathrm{~m}$, $11 \mathrm{H}), 7.78(\mathrm{~d}, J=8.0 \mathrm{~Hz}, 1 \mathrm{H}), 7.30\left(\mathrm{~s}, 1 \mathrm{H}, \mathrm{NH}_{2}\right), 7.11(\mathrm{dd}, J=21.5,4.5 \mathrm{~Hz}, 10 \mathrm{H}, \mathrm{Ar}$ of Phe), $7.04\left(\mathrm{~s}, 1 \mathrm{H}, \mathrm{NH}_{2}\right), 4.44-4.36\left(\mathrm{~m}, 2 \mathrm{H}, \mathrm{H}_{\alpha}\right.$, Phe), 4.25-4.16 (m, 4H, overlapping signal $\mathrm{H}_{\alpha}$ Glu and Gly), 3.72-3.71 (d, J = 4.1 Hz, 2H, Pyrene), 3.01-2.88 (m, 2H, $\mathrm{H}_{\beta}$, Phe), 2.82-2.63 (m, $2 \mathrm{H}, \mathrm{H}_{\beta}$, Phe), 2.20-2.09 (m, 4H, m, $\left.\mathrm{H}_{\gamma}, \mathrm{Glu}\right), 1.86-1.58$ (m, 4H, $\left.\mathrm{H}_{\beta}, \mathrm{Glu}\right)$ ppm.

${ }^{13} \mathrm{C}-\mathrm{NMR}$ (DMSO-d6, $\left.75 \mathrm{MHz}\right) \delta 174.79,174.73,173.42,171.91,171.86,171.47,169.85$, $138.54,138.50,131.63,131.52,131.18,130.58,129.97,129.85,129.49,128.84,128.78,128.19$, $128.08,127.64,126.98,125.87,125.72,125.56,124.90,124.73,54.73,54.49,53.06,52.72,43.10$, $38.30,37.72,30.83,28.13,20.02$.

FT-IR (KBr): $\widetilde{v}\left(\mathrm{~cm}^{-1}\right)=3403,3311,3030,2927,1737,1722,1659,1652,1615,1540,14,898$, 1453, 1443, 1409, 1272, 1185, 1170, 846, 792, 744, 699, 646, 496.

\subsection{Gel Preparation}

$\mathrm{pH}$ triggered gelation: a known amount of $\mathbf{1}$ was introduced to a $4 \mathrm{~mL}$ vial. Then, $900 \mu \mathrm{L}$ of milliQ water was added. $\mathrm{NaOH} 1 \mathrm{M}$ was added in portions of $10 \mu \mathrm{L}$ until a clear solution through sonication was obtained followed by addition of water to a final volume of $1 \mathrm{~mL}$. Then, $\mathrm{HCl} 1 \mathrm{M}$ was added in portions. Gel formation was assessed by the vial inversion test.

Alkali metal salt induced gelation: a known amount of 1 was introduced to a $4 \mathrm{~mL}$ vial. Then, $900 \mu \mathrm{L}$ of milliQ water was added. $\mathrm{NaOH} 1 \mathrm{M}$ was added in portions of $10 \mu \mathrm{L}$ until a clear solution was obtained (sonication) followed by addition of water to a final volume of $1 \mathrm{~mL}$. Then, a solution of alkali salt $1 \mathrm{M}$ was added in portions of $10 \mu \mathrm{L}$ until gel formation was observed. Gel formation was assessed by the vial inversion test.

Bi-and-trivalent metal salts induced gelation: a known amount of $\mathbf{1}$ was introduced to a $4 \mathrm{~mL}$ vial. Then, $900 \mu \mathrm{L}$ of milliQ water was added. $\mathrm{NaOH} 1 \mathrm{M}$ was added in portions of $10 \mu \mathrm{L}$ until a clear solution was obtained (sonication) followed by addition of water to a final volume of $1 \mathrm{~mL}$. Then, a solution of salt $0.05 \mathrm{M}$ was added at a 1:1 ratio with compound 1 . Gel formation was assessed by the vial inversion test.

The temperatures of gel-to-sol transition were determined as follows: $1 \mathrm{~mL}$ of gel at the appropriate concentration was prepared in a clear glass vial. The vial was sealed, placed tilted on thermostated oil bath, and heated at a rate of $0.5^{\circ} \mathrm{C} / \mathrm{min}$. The temperature at which the gel starts to break down was defined as Tgel. The measurement was repeated at least twice, and the average value is reported. Tgel values were found to be almost unaltered within a difference of $1-2{ }^{\circ} \mathrm{C}$ after two heating-cooling cycles.

Supplementary Materials: The following are available online at https: / www.mdpi.com/article/ 10.3390/gels7030085/s1, Figure S1: ESI-MS of compound 1, Figure S2: (a) ${ }^{1} \mathrm{H}$ NMR (DMSO-d6, $300 \mathrm{MHz}$ ) of $\mathbf{1}$, (b) ${ }^{13} \mathrm{C}-\mathrm{NMR}\left(\mathrm{DMSO}-\mathrm{d}_{6}, 300 \mathrm{MHz}\right.$ ) of 1, Figure S3: FT-IR spectrum of $\mathbf{1}$ (KBr disk), Figure S4: Non-normalized emission spectra of $\mathbf{1}$ in basic water at $0.5 \%$ (solid line) and at $0.005 \%$ (dotted line), Figure S5: Normalized absorption spectra of $\mathbf{1}$ in basic water at $0.5 \%$ (solid line) and at $0.005 \%$ (dotted line), Figure S6: CD spectra of $\mathbf{1}$ in basic water at $0.5 \%$ (solid line) and at $0.005 \%$ 
(dotted line), Figure S7: ATR-FTIR spectrum of $\mathbf{1}$ (solid line) and the lyophilized deprotonated sample (dotted line), Figure S8: Amplitude sweep experiment of the 1- $\mathrm{HCl}$ gel, Figure S9: Picture of vials containing the hydrogels obtained with the different triggers, Figure S10: ATR-FTIR spectra of the monovalent cation induced hydrogels recorded on the lyophilized samples, Figure S11: ATR-FTIR spectra of divalent and trivalent cation induced hydrogels recorded on the lyophilized samples, Figure S12: CD-spectra of the monovalent cation induced hydrogels, Figures S13-S24: TEM images of the hydrogels, Figures S25 and S26: Amplitude sweep experiments of metal-induced hydrogels; Table S1: Average value of $\mathrm{G}^{\prime}$ and $\mathrm{G}^{\prime \prime}$ and the flow point, Figure S27: Colorimetric responses of the 1- $\mathrm{Cu}^{2+}$ gel to methylamine, diethylammine, and triethylammine, Figure S28: Photo of cuvettes containing hydrogels and adsorbed methylene blue, Figure S29: Absorption spectra of a $15 \mathrm{mg} / \mathrm{L}$ solution of methylene blue in the presence of 1- $\mathrm{HCl}$ hydrogel, Figure S30: Absorption spectra of a $15 \mathrm{mg} / \mathrm{L}$ solution of methylene blue in the presence of 1-Na+ hydrogel, Figure S31: Absorption spectra of a $15 \mathrm{mg} / \mathrm{L}$ solution of methylene blue in the presence of $1-\mathrm{Zn}^{2+}$ hydrogel, Figure S32: Absorption spectra of a $10 \mathrm{mg} / \mathrm{L}$ solution of methylene blue in the presence of $1-\mathrm{Zn}^{2+}$ xerogel, Figure S33: Absorption spectra of a $10 \mathrm{mg} / \mathrm{L}$ solution of methyl orange in the presence of $1-\mathrm{Zn}^{2+}$ xerogel, Figure S34: Absorption spectra of a mixture of methylene blue and methyl orange, $5 \mathrm{mg} / \mathrm{mL}$, in the presence of $1-\mathrm{Zn}^{2+}$ xerogel.

Author Contributions: Conceptualization, A.F. and M.M.; investigation, A.F. and M.M., writingoriginal draft preparation, A.F. and M.M.; writing-review and editing, M.M.; visualization, A.F.; supervision, M.M.; project administration, M.M. All authors have read and agreed to the published version of the manuscript.

Funding: This research received no external funding.

Institutional Review Board Statement: Not applicable.

Informed Consent Statement: Not applicable.

Data Availability Statement: The data presented in this study are available in the article.

Conflicts of Interest: The authors declare no conflict of interest.

\section{References}

1. Draper, E.R.; Adams, D.J. Low-Molecular-Weight Gels: The State of the Art. Chem 2017, 3, 390-410. [CrossRef]

2. Du, X.W.; Zhou, J.; Shi, J.F.; Xu, B. Supramolecular Hydrogelators and Hydrogels: From Soft Matter to Molecular Biomaterials. Chem. Rev. 2015, 115, 13165-13307. [CrossRef]

3. Escuder, B.; Miravet, J.F. Functional Molecular Gels; Royal Society of Chemistry: Cambridge, UK, 2013.

4. Yu, X.; Chen, L.; Zhang, M.; Yi, T. Low-molecular-mass gels responding to ultrasound and mechanical stress: Towards self-healing materials. Chem. Soc. Rev. 2014, 43, 5346-5371. [CrossRef] [PubMed]

5. Jones, C.D.; Steed, J.W. Gels with sense: Supramolecular materials that respond to heat, light and sound. Chem. Soc. Rev. 2016, 45, 6546-6596. [CrossRef]

6. Zhang, C.W.; Ou, B.; Jiang, S.T.; Yin, G.Q.; Chen, L.J.; Xu, L.; Li, X.P.; Yang, H.B. Cross-linked AIE supramolecular polymer gels with multiple stimuli-responsive behaviours constructed by hierarchical self-assembly. Polym. Chem. 2018, 9, 2021-2030. [CrossRef]

7. Sun, Z.F.; Huang, Q.Y.; He, T.; Li, Z.Y.; Zhang, Y.; Yi, L.Z. Multistimuli-Responsive Supramolecular Gels: Design Rationale, Recent Advances, and Perspectives. ChemPhysChem 2014, 15, 2421-2430. [CrossRef] [PubMed]

8. Xian, S.; Webber, M.J. Temperature-responsive supramolecular hydrogels. J. Mat. Chem. B 2020, 8, 9197-9211. [CrossRef] [PubMed]

9. Tam, A.Y.-Y.; Yam, V.W.-W. Recent advances in metallogels. Chem. Soc. Rev. 2013, 42, 1540-1567. [CrossRef]

10. Wu, H.; Zheng, J.; Kjøniksen, A.-L.; Wang, W.; Zhang, Y.; Ma, J. Metallogels: Availability, Applicability, and Advanceability. Adv. Mater. 2019, 31, 1806204. [CrossRef]

11. Piepenbrock, M.O.M.; Lloyd, G.O.; Clarke, N.; Steed, J.W. Metal- and Anion-Binding Supramolecular Gels. Chem. Rev. 2010, 110, 1960-2004. [CrossRef]

12. Sutar, P.; Maji, T.K. Recent advances in coordination-driven polymeric gel materials: Design and applications. Dalton Trans. 2020, 49, 7658-7672. [CrossRef]

13. Huang, J.; He, L.; Zhang, J.; Chen, L.; Su, C.-Y. Dynamic functionalised metallogel: An approach to immobilised catalysis with improved activity. J. Mol. Catal. A: Chem. 2010, 317, 97-103. [CrossRef]

14. Naseer, F.; Ajmal, M.; Bibi, F.; Farooqi, Z.H.; Siddiq, M. Copper and cobalt nanoparticles containing poly(acrylic acid-coacrylamide) hydrogel composites for rapid reduction of 4-nitrophenol and fast removal of malachite green from aqueous medium. Polym. Compos. 2018, 39, 3187-3198. 
15. Lin, Q.; Lu, T.-T.; Zhu, X.; Wei, T.-B.; Li, H.; Zhang, Y.-M. Rationally introduce multi-competitive binding interactions in supramolecular gels: A simple and efficient approach to develop multi-analyte sensor array. Chem. Sci. 2016, 7, 5341-5346. [PubMed]

16. Liu, J.; He, P.; Yan, J.; Fang, X.; Peng, J.; Liu, K.; Fang, Y. An organometallic super-gelator with multiple-stimulus responsive properties. Adv. Mater. 2008, 20, 2508-2511.

17. Sun, Z.; Li, Z.; He, Y.; Shen, R.; Deng, L.; Yang, M.; Liang, Y.; Zhang, Y. Ferrocenoyl phenylalanine: A new strategy toward supramolecular hydrogels with multistimuli responsive properties. J. Am. Chem. Soc. 2013, 135, 13379-13386. [CrossRef] [PubMed]

18. Shirakawa, M.; Fujita, N.; Tani, T.; Kaneko, K.; Shinkai, S. Organogel of an 8-quinolinol platinum (II) chelate derivative and its efficient phosphorescence emission effected by inhibition of dioxygen quenching. Chem. Commun. 2005, 4149-4151. [CrossRef]

19. Dixit, M.K.; Mahendar, C.; Dubey, M. Cd2+-induced Fluorescent Metallogel: A case of CHEF and ACQ phenomenon. Chem. Asian, J. 2019. [CrossRef]

20. Basak, S.; Nanda, J.; Banerjee, A. Multi-stimuli responsive self-healing metallo-hydrogels: Tuning of the gel recovery property. Chem. Commun. 2014, 50, 2356-2359.

21. Häring, M.; Díaz, D.D. Supramolecular metallogels with bulk self-healing properties prepared by in situ metal complexation. Chem. Commun. 2016, 52, 13068-13081. [CrossRef]

22. Sharma, B.; Singh, A.; Sarma, T.K.; Sardana, N.; Pal, A. Chirality control of multi-stimuli responsive and self-healing supramolecular metallo-hydrogels. New, J. Chem. 2018, 42, 6427-6432. [CrossRef]

23. Koutsopoulos, S. Self-assembling peptide nanofiber hydrogels in tissue engineering and regenerative medicine: Progress, design guidelines, and applications. J. Biomed. Mater. Res. Part. A 2016, 104, 1002-1016. [CrossRef]

24. Lu, J.; Wang, X. Biomimetic Self-Assembling Peptide Hydrogels for Tissue Engineering Applications. In Biomimetic Medical Materials: From Nanotechnology to 3D Bioprinting; Noh, I., Ed.; Springer: Singapore, 2018; pp. 297-312.

25. Lian, M.; Chen, X.; Lu, Y.; Yang, W. Self-assembled peptide hydrogel as a smart biointerface for enzyme-based electrochemical biosensing and cell monitoring. ACS Appl. Mater. Interfaces 2016, 8, 25036-25042. [CrossRef] [PubMed]

26. Souza, S.F.; Silva, E.R.; Alves, W.A. Nanostructured antigen-responsive hydrogels based on peptides for leishmaniasis detection. J. Braz. Chem. Soc. 2017, 28, 1619-1629. [CrossRef]

27. King, P.J.; Saiani, A.; Bichenkova, E.V.; Miller, A.F. A de novo self-assembling peptide hydrogel biosensor with covalently immobilised DNA-recognising motifs. Chem. Commun. 2016, 52, 6697-6700.

28. Naskar, J.; Palui, G.; Banerjee, A. Tetrapeptide-Based Hydrogels: For Encapsulation and Slow Release of an Anticancer Drug at Physiological pH. J. Phys. Chem. B 2009, 113, 11787-11792. [CrossRef] [PubMed]

29. Thota, C.K.; Yadav, N.; Chauhan, V.S. A novel highly stable and injectable hydrogel based on a conformationally restricted ultrashort peptide. Sci. Rep. 2016, 6, 1-12. [CrossRef] [PubMed]

30. Yu, Z.; Xu, Q.; Dong, C.; Lee, S.S.; Gao, L.; Li, Y.; D’Ortenzio, M.; Wu, J. Self-assembling peptide nanofibrous hydrogel as a versatile drug delivery platform. Curr. Pharm. Des. 2015, 21, 4342-4354. [CrossRef]

31. Stupp, S.I.; Palmer, L.C. Supramolecular chemistry and self-assembly in organic materials design. Chem. Mater. 2014, 26, 507-518. [CrossRef]

32. Mondal, S.; Das, S.; Nandi, A.K. A review on recent advances in polymer and peptide hydrogels. Soft Matter 2020, 16, 1404-1454 [CrossRef]

33. Gong, C.; Sun, S.; Zhang, Y.; Sun, L.; Su, Z.; Wu, A.; Wei, G. Hierarchical nanomaterials via biomolecular self-assembly and bioinspiration for energy and environmental applications. Nanoscale 2019, 11, 4147-4182. [CrossRef]

34. Martin, A.D.; Thordarson, P. Beyond Fmoc: A review of aromatic peptide capping groups. J. Mat. Chem. B 2020,8 , 863-877. [CrossRef]

35. Draper, E.R.; Adams, D.J. Controlling the Assembly and Properties of Low-Molecular-Weight Hydrogelators. Langmuir 2019, 35, 6506-6521. [CrossRef]

36. Adams, D.J.; Butler, M.F.; Frith, W.J.; Kirkland, M.; Mullen, L.; Sanderson, P. A new method for maintaining homogeneity during liquid-hydrogel transitions using low molecular weight hydrogelators. Soft Matter 2009, 5, 1856-1862. [CrossRef]

37. Kaur, H.; Sharma, P.; Patel, N.; Pal, V.K.; Roy, S. Accessing Highly Tunable Nanostructured Hydrogels in a Short Ionic Complementary Peptide Sequence via pH Trigger. Langmuir 2020, 36, 12107-12120. [CrossRef] [PubMed]

38. Shi, J.F.; Gao, Y.; Zhang, Y.; Pan, Y.; Xu, B. Calcium Ions to Cross-Link Supramolecular Nanofibers to Tune the Elasticity of Hydrogels over Orders of Magnitude. Langmuir 2011, 27, 14425-14431. [CrossRef]

39. Chen, L.; Pont, G.; Morris, K.; Lotze, G.; Squires, A.; Serpell, L.C.; Adams, D.J. Salt-induced hydrogelation of functionaliseddipeptides at high pH. Chem. Commun. 2011, 47, 12071-12073. [CrossRef] [PubMed]

40. Chen, L.; McDonald, T.O.; Adams, D.J. Salt-induced hydrogels from functionalised-dipeptides. RSC Adv. 2013, 3, 8714-8720. [CrossRef]

41. Shao, T.; Falcone, N.; Kraatz, H.B. Supramolecular Peptide Gels: Influencing Properties by Metal Ion Coordination and Their Wide-Ranging Applications. ACS Omega 2020, 5, 1312-1317. [CrossRef] [PubMed]

42. Basak, S.; Singh, I.; Kraatz, H.-B. Ion-Dependent Modulation of Self-Healing Hydrogels. ChemistrySelect 2017, 2, $451-457$. [CrossRef] 
43. Ji, W.; Yuan, C.; Zilberzwige-Tal, S.; Xing, R.; Chakraborty, P.; Tao, K.; Gilead, S.; Yan, X.; Gazit, E. Metal-Ion Modulated Structural Transformation of Amyloid-Like Dipeptide Supramolecular Self-Assembly. ACS Nano 2019, 13, 7300-7309. [CrossRef]

44. Fu, W.; Farhadi Sabet, Z.; Liu, J.; You, M.; Zhou, H.; Wang, Y.; Gao, Y.; Li, J.; Ma, X.; Chen, C. Metal ions modulation of the self-assembly of short peptide conjugated nonsteroidal anti-inflammatory drugs (NSAIDs). Nanoscale 2020, 12, 7960-7968. [CrossRef] [PubMed]

45. Erdoğan, H. Cation-based approach to morphological diversity of diphenylalanine dipeptide structures. Soft Matter $\mathbf{2 0 2 1}$ [CrossRef]

46. McEwen, H.; Du, E.Y.; Mata, J.P.; Thordarson, P.; Martin, A.D. Tuning hydrogels through metal-based gelation triggers. J. Mat. Chem. B 2017, 5, 9412-9417. [CrossRef] [PubMed]

47. Sharma, P.; Kaur, H.; Roy, S. Inducing Differential Self-Assembling Behavior in Ultrashort Peptide Hydrogelators Using Simple Metal Salts. Biomacromol. 2019, 20, 2610-2624. [CrossRef] [PubMed]

48. Kumar, S.; Nandi, S.K.; Suman, S.; Haldar, D. A new dipeptide as a selective gelator of $\mathrm{Cu}(\mathrm{ii}), \mathrm{Zn}(\mathrm{ii})$, and Pb(ii). CrystEngComm 2020, 22, 7975-7982. [CrossRef]

49. Micklitsch, C.M.; Knerr, P.J.; Branco, M.C.; Nagarkar, R.; Pochan, D.J.; Schneider, J.P. Zinc-Triggered Hydrogelation of a SelfAssembling beta-Hairpin Peptide. Angew. Chem. Int. Ed. 2011, 50, 1577-1579. [CrossRef] [PubMed]

50. Dey, S.; Misra, R.; Saseendran, A.; Pahan, S.; Gopi, H.N. Metal-Coordinated Supramolecular Polymers from the Minimalistic Hybrid Peptide Foldamers. Angew. Chem. Int. Ed. 2021, 60, 9863-9868. [CrossRef] [PubMed]

51. Gayen, K.; Basu, K.; Bairagi, D.; Castelletto, V.; Hamley, I.W.; Banerjee, A. Amino-Acid-Based Metallo-Hydrogel That Acts Like an Esterase. ACS Appl. Bio Mater. 2018, 1, 1717-1724. [CrossRef]

52. Zhang, Y.; Zhang, B.; Kuang, Y.; Gao, Y.; Shi, J.; Zhang, X.X.; Xu, B. A Redox Responsive, Fluorescent Supramolecular Metallohydrogel Consists of Nanofibers with Single-Molecule Width. J. Am. Chem. Soc. 2013, 135, 5008-5011. [CrossRef]

53. Aneja, V.P.; Chauhan, J.; Walker, J. Characterization of atmospheric ammonia emissions from swine waste storage and treatment lagoons. J. Geophys. Res. Atmos. 2000, 105, 11535-11545. [CrossRef]

54. Aneja, V.P.; Roelle, P.A.; Murray, G.C.; Southerland, J.; Erisman, J.W.; Fowler, D.; Asman, W.A.; Patni, N. Atmospheric nitrogen compounds II: Emissions, transport, transformation, deposition and assessment. Atmos. Environ. 2001, 35, 1903-1911. [CrossRef]

55. Gao, T.; Tillman, E.S.; Lewis, N.S. Detection and classification of volatile organic amines and carboxylic acids using arrays of carbon black-dendrimer composite vapor detectors. Chem. Mater. 2005, 17, 2904-2911. [CrossRef]

56. Landete, J.M.; de Las Rivas, B.; Marcobal, A.; Muñoz, R. Molecular methods for the detection of biogenic amine-producing bacteria on foods. Int. J. Food Microbiol. 2007, 117, 258-269. [CrossRef] [PubMed]

57. Doeun, D.; Davaatseren, M.; Chung, M.-S. Biogenic amines in foods. Food Sci. Biotech. 2017, 26, 1463-1474. [CrossRef] [PubMed]

58. Naila, A.; Flint, S.; Fletcher, G.; Bremer, P.; Meerdink, G. Control of biogenic amines in food-existing and emerging approaches. J. Food Sci. 2010, 75, R139-R150. [CrossRef] [PubMed]

59. Ruiz-Capillas, C.; Herrero, A.M. Impact of biogenic amines on food quality and safety. Foods 2019, 8, 62. [CrossRef] [PubMed]

60. Suzzi, G.; Gardini, F. Biogenic amines in dry fermented sausages: A review. Int. J. Food Microbiol. 2003, 88, 41-54. [CrossRef]

61. Visciano, P.; Schirone, M.; Tofalo, R.; Suzzi, G. Biogenic amines in raw and processed seafood. Front. Microbiol. 2012, 3, 188. [CrossRef] [PubMed]

62. Wu, T.H.; Bechtel, P.J. Ammonia, dimethylamine, trimethylamine, and trimethylamine oxide from raw and processed fish by-products. J. Aquat. Food Prod.Technol. 2008, 17, 27-38. [CrossRef]

63. Devarayan, K.; Motcham, V.V.; Kathavarayan, M.; Anjappan, H. Real-Time Detection of Packaged Seer Fish Spoilage Using Halochromic Optical Nose. J. Aquat. Food Prod.Technol. 2021, 30, 484-495. [CrossRef]

64. Steiner, M.-S.; Meier, R.J.; Duerkop, A.; Wolfbeis, O.S. Chromogenic sensing of biogenic amines using a chameleon probe and the red-green- blue readout of digital camera images. Anal. Chem. 2010, 82, 8402-8405. [CrossRef]

65. Tang, Z.; Yang, J.; Yu, J.; Cui, B. A colorimetric sensor for qualitative discrimination and quantitative detection of volatile amines. Sensors 2010, 10, 6463-6476. [CrossRef]

66. Fan, J.; Chang, X.; He, M.; Shang, C.; Wang, G.; Yin, S.; Peng, H.; Fang, Y. Functionality-Oriented Derivatization of Naphthalene Diimide: A Molecular Gel Strategy-Based Fluorescent Film for Aniline Vapor Detection. ACS Appl. Mater. Interfaces 2016, 8 , 18584-18592. [CrossRef] [PubMed]

67. Cao, X.; Ding, Q.; Li, Y.; Gao, A.; Chang, X. Continuous multi-channel sensing of volatile acid and organic amine gases using a fluorescent self-assembly system. J. Mater. Chem C. 2019, 7, 133-142. [CrossRef]

68. Pang, X.; Yu, X.; Lan, H.; Ge, X.; Li, Y.; Zhen, X.; Yi, T. Visual Recognition of Aliphatic and Aromatic Amines Using a Fluorescent Gel: Application of a Sonication-Triggered Organogel. ACS Appl. Mater. Interfaces 2015, 7, 13569-13577. [CrossRef] [PubMed]

69. Cao, X.; Gao, A.; Hou, J.-T.; Yi, T. Fluorescent supramolecular self-assembly gels and their application as sensors: A review. Coord. Chem. Rev. 2021, 434, 213792. [CrossRef]

70. Xue, P.; Sun, J.; Yao, B.; Gong, P.; Zhang, Z.; Qian, C.; Zhang, Y.; Lu, R. Strong Emissive Nanofibers of Organogels for the Detection of Volatile Acid Vapors. Chem. Eur. J. 2015, 21, 4712-4720. [CrossRef] [PubMed]

71. Xue, P.; Yao, B.; Wang, P.; Gong, P.; Zhang, Z.; Lu, R. Strong Fluorescent Smart Organogel as a Dual Sensing Material for Volatile Acid and Organic Amine Vapors. Chem. Eur. J. 2015, 21, 17508-17515. [CrossRef]

72. Wang, S.S.; Xue, P.C.; Wang, P.P.; Yao, B.Q. Emission enhanced two-component gels for the detection of organic amine vapors. New J. Chem. 2015, 39, 6874-6881. [CrossRef] 
73. Sengupta, S.; Mondal, R. A novel low molecular weight supergelator showing an excellent gas adsorption, dye adsorption, self-sustaining and chemosensing properties in the gel state. RSC Adv. 2016, 6, 14009-14015. [CrossRef]

74. Tang, L.Y.; Liao, S.S.; Qu, J.Q. Self-Healing and Multistimuli-Responsive Hydrogels Formed via a Cooperation Strategy and Their Application in Detecting Biogenic Amines. ACS Appl. Mater. Interfaces 2018, 10, 27365-27373. [CrossRef] [PubMed]

75. Gu, D.; Yang, W.; Lin, D.; Qin, X.; Yang, Y.; Wang, F.; Pan, Q.; Su, Z. Water-stable lanthanide-based metal-organic gel for the detection of organic amines and white-light emission. J. Mater. Chem C. 2020, 8, 13648-13654. [CrossRef]

76. Kant, R. Textile dyeing industry an environmental hazard. Nat. Sci. 2011, 4, 22-26. [CrossRef]

77. Robinson, T.; McMullan, G.; Marchant, R.; Nigam, P. Remediation of dyes in textile effluent: A critical review on current treatment technologies with a proposed alternative. Bioresour. Technol. 2001, 77, 247-255. [CrossRef]

78. Yagub, M.T.; Sen, T.K.; Afroze, S.; Ang, H.M. Dye and its removal from aqueous solution by adsorption: A review. Adv. Colloid Interface Sci. 2014, 209, 172-184. [CrossRef] [PubMed]

79. Okesola, B.O.; Smith, D.K. Applying low-molecular weight supramolecular gelators in an environmental setting-self-assembled gels as smart materials for pollutant removal. Chem. Soc. Rev. 2016, 45, 4226-4251. [CrossRef]

80. Adhikari, B.; Palui, G.; Banerjee, A. Self-assembling tripeptide based hydrogels and their use in removal of dyes from waste-water. Soft Matter 2009, 5, 3452-3460. [CrossRef]

81. Li, Y.; Wang, L. Removing Organic Dyes by Using a Small Peptide Hydrogel. Chem. Lett. 2016, 45, 1253-1255. [CrossRef]

82. Basak, S.; Nandi, N.; Paul, S.; Hamley, I.W.; Banerjee, A. A tripeptide-based self-shrinking hydrogel for waste-water treatment: Removal of toxic organic dyes and lead (Pb2+) ions. Chem. Commun. 2017, 53, 5910-5913. [CrossRef]

83. Roy, K.; Chetia, M.; Sarkar, A.K.; Chatterjee, S. Co-assembly of charge complementary peptides and their applications as organic dye/heavy metal ion $\left(\mathrm{Pb}^{2+}, \mathrm{Hg}^{2+}\right)$ absorbents and arsenic(iii/v) detectors. RSC Adv. 2020, 10, 42062-42075. [CrossRef]

84. Chetia, M.; Debnath, S.; Chowdhury, S.; Chatterjee, S. Self-assembly and multifunctionality of peptide organogels: Oil spill recovery, dye absorption and synthesis of conducting biomaterials. RSC Adv. 2020, 10, 5220-5233. [CrossRef]

85. Mondal, B.; Bairagi, D.; Nandi, N.; Hansda, B.; Das, K.S.; Edwards-Gayle, C.J.C.; Castelletto, V.; Hamley, I.W.; Banerjee, A. Peptide-Based Gel in Environmental Remediation: Removal of Toxic Organic Dyes and Hazardous Pb2+ and Cd2+ Ions from Wastewater and Oil Spill Recovery. Langmuir 2020, 36, 12942-12953. [CrossRef]

86. Qin, L.; Xie, F.; Duan, P.F.; Liu, M.H. A Peptide Dendron-Based Shrinkable Metallo-Hydrogel for Charged Species Separation and Stepwise Release of Drugs. Chem. Eur. J. 2014, 20, 15419-15425. [CrossRef] [PubMed]

87. Ray, S.; Das, A.K.; Banerjee, A. pH-Responsive, Bolaamphiphile-Based Smart Metallo-Hydrogels as Potential Dye-Adsorbing Agents, Water Purifier, and Vitamin B12 Carrier. Chem. Mater. 2007, 19, 1633-1639. [CrossRef]

88. Davies, R.; Aggeli, A.; Beevers, A.; Boden, N.; Carrick, L.; Fishwick, C.; McLeish, T.; Nyrkova, I.; Semenov, A. Self-assembling $\beta$-sheet tape forming peptides. Supramol. Chem. 2006, 18, 435-443. [CrossRef]

89. Lee, N.R.; Bowerman, C.J.; Nilsson, B.L. Sequence length determinants for self-assembly of amphipathic $\beta$-sheet peptides. Pept. Sci. 2013, 100, 738-750. [CrossRef] [PubMed]

90. Lee, N.R.; Bowerman, C.J.; Nilsson, B.L. Effects of varied sequence pattern on the self-assembly of amphipathic peptides. Biomacromolecules 2013, 14, 3267-3277. [CrossRef] [PubMed]

91. Winnik, F.M. Photophysics of preassociated pyrenes in aqueous polymer solutions and in other organized media. Chem. Rev. 1993, 93, 587-614. [CrossRef]

92. Yang, H.-K.; Su, M.-M.; Ren, L.-J.; Zheng, P.; Wang, W. Enhanced thermal stability of organogels through self-reinforcing supramolecular assembly of a cholesterol-polyoxomatalate-cholesterol hybrid gelator. RSC Adv. 2014, 4, 1138-1145. [CrossRef]

93. Wu, Y.; Liu, K.; Chen, X.; Chen, Y.; Zhang, S.; Peng, J.; Fang, Y. A novel calix[4]arene-based dimeric-cholesteryl derivative: Synthesis, gelation and unusual properties. New J. Chem. 2015, 39, 639-649. [CrossRef]

94. Sawada, H.; Yamanaka, M. Synthesis of a Bis-Urea Dimer and Its Effects on the Physical Properties of an Amphiphilic Tris-Urea Supramolecular Hydrogel. Chem. Asian J. 2018, 13, 929-933. [CrossRef] [PubMed]

95. Alegre-Requena, J.V.; Grijalvo, S.; Sampedro, D.; Mayr, J.; Saldías, C.; Marrero-Tellado, J.J.; Eritja, R.; Herrera, R.P.; Díaz, D.D. Sulfonamide as amide isostere for fine-tuning the gelation properties of physical gels. RSC Adv. 2020, 10, 11481-11492. [CrossRef]

96. Barth, A. Infrared spectroscopy of proteins. Biochim. Biophys. Acta Bioenerget. 2007, 1767, 1073-1101. [CrossRef]

97. Jackson, M.; Mantsch, H.H. The Use and Misuse of FTIR Spectroscopy in the Determination of Protein Structure. Crit. Rev. Biochem. Mol. Biol. 1995, 30, 95-120. [CrossRef]

98. Greenfield, N.J.; Fasman, G.D. Computed circular dichroism spectra for the evaluation of protein conformation. Biochemistry 1969, 8, 4108-4116. [CrossRef]

99. Kelly, S.M.; Jess, T.J.; Price, N.C. How to study proteins by circular dichroism. Biochim. Biophys. Acta Proteins Proteom. 2005, 1751, 119-139. [CrossRef] [PubMed]

100. Berova, N.; Polavarapu, P.L.; Nakanishi, K.; Woody, R.W. Comprehensive Chiroptical Spectroscopy: Applications in Stereochemical Analysis of Synthetic Compounds, Natural Products, and Biomolecules; John Wiley \& Sons: Hoboken, NJ, USA, 2012 ; Volume 2.

101. Garifullin, R.; Guler, M.O. Supramolecular chirality in self-assembled peptide amphiphile nanostructures. Chem. Commun. 2015, 51, 12470-12473. [CrossRef] 